\title{
Down Standardization Process and Prospects
}

\author{
Wang Yicheng ${ }^{1}$, Wang Shaoping ${ }^{2, *}$ \\ ${ }^{1}$ School of Life Seience and Biotechnology, Dalian University of Technology, Dalian, China \\ ${ }^{2}$ National Textile and Apparel Products Quality Supervision and Inspection Center (Fujian), Fuzhou, China
}

\section{Email address:}

327551758@qq.com (Wang Shaoping)

${ }^{*}$ Corresponding author

\section{To cite this article:}

Wang Yicheng, Wang Shaoping. Down Standardization Process and Prospects. American Journal of Biomedical and Life Sciences. Vol. 7, No. 3, 2019, pp. 57-62. doi: 10.11648/j.ajbls.20190703.13

Received: February 21, 2019; Accepted: April 4, 2019; Published: July 11, 2019

\begin{abstract}
The internationalization process of the standardization development of down products in China is relatively slow. This paper analyzes the standardization of the national standard and international standard of down products, between the current domestic and international standards for down products, there are some differences in the type of project and the limit value of the index. The development idea of improving the quality of down products by promoting the standardization of down products is put forward. The purpose is to promote the international development process of the down industry in China.
\end{abstract}

Keywords: Down and Feather, Standardization, Prospects, Development

\section{Introduction}

Standards are closely linked to quality. Standardization is the foundation of quality management and the basis for leading the quality development. In turn, the general improvement of quality has contributed to the improvement of the level of standardization. Analysis and research on the development of down product standardization in China, has a leading and guiding role in the improvement of the quality of down products, has a positive role in promoting and promoting the standardization process of down products. The current Chinese national standards for down products are as follows: GB/T 14272-2011 Down garments [1], GB/T 10288-2016 Test method for down and feather [2], and GB/T 17685-2016 Down and feather [3]. The current international standard for down products is represented by the IDFB Standard (2017 Edition) [4] of the International Down and Feather Bureau. Through comparative analysis, technical requirements of Chinese standards for down products compared to international standards, there are some differences in the type of project and the limit value of the index. Therefore, analyzing the differences between Chinese and international standardization of down products, discussion on the process of promoting the standardization of the down products in China, thus leading the international development of China's down industry.

\section{The Standardization of Down and Feather in International}

At present, the international standards for the quality inspection of down are IDFB standards, as well as the British standards, German standards, European standards, American standards and Japanese standards.

The international standards for the quality inspection of down, which was developed and implemented by the Technical Committee of the International Down and Feather Bureau (IDFB) [4], is called "Official Analysis Method". The main contents of version 2017 include sample conditingtion, sample sampling, composition (content analysis), fat and oil, moisture, acidity (pHvalue), oxygen number, fill power with steam conditioning, turbidity, feather and down species, feather pre-sort, average feather length, composition of blended filling materials, color separation, net fill weight (mass), evaluation of durable water repellent treatments (DWR), compression and recovery of loose fillings, fabric and down proof testing.

At present, the main international standards related to the technical barriers to trade in down garments are BS EN 1161:1997 Feather and down-Test methods-Determination of moisture content [5], BS EN 1162:1997 Feather and 
down-Test methods-Determination of the oxygen index number [6], BS EN 1163:1997Feather and down-Test methods-Determination of the oil and fat content [7], BS EN 1164:1999Feather and down-Test methods-Determination of the turbidity of an aqueous extract [8], EN 12935:2001 Feather and down-Hygiene and cleanliness requirements [9], BS EN 1884:1999 Feather and Down-Test Methods-determination of microbiological state [10], Standard 100 by OEKO-TEX (Edition01.2019) Conditions for testing, certification and licensing according [11]. The European Commission for Standardization has issued a series of down and its product standards after 1990. The Federal Trade Commission (FTC) Textile fiber content and washing maintenance label requirements. the Consumer Product Safety Commission (CPSC) Standard for flame retardancy of textile and clothing products, and JIS L 1903:2017 Testing methods for feathers [12].

\section{The Standardization of Down and Feather in China}

Around 1990, it was the development period of the down industry in China, the export of down products has increased year by year. Down products is generally welcomed by consumers because of unique soft, light, loose, warm characteristics. In order to standardize the quality of down products for export, the national standards GB/T 10288-1988Inspection method of feather for export [13], and GB/T 10289-1988Inspection method of washed feather for export [14] were issued and implemented. In 1991, four industry standards for down bedding, such as: QB/T 1193-1991 Down quilt [15], QB/T 1194-1991 Down sleeper [16], QB/T 1195-1991 Down sleeping bag [17], and QB/T 1196-1991 Down pillow [18], were issued and implemented by the former Ministry of Light Industry, which initiated the standardization process of down products in China, and provided the basis for standardizing the down product quality However, in the above standards, there were some limitations in the scope of application and the setting of detection index.

On May 1, 2004, a new national standard for down products GB/T 10288-2003 Testing methods for down and feather [19] was issued and implemented. The standard adopted the hygienic requirements of microbes in European standards, and increased the detection of mesophil aerobic bacteria, faecal streptococci, sulphite reducing clostridium and salmonellae. It is specified that when the "oxygen consumption" index exceeds 10mg/ 100g, the microbial index detection must be carried out, the quality supervision of the health and safety performance of the down products is strengthened. This requirement is even higher than European standards, it is better to regulate the development of enterprises and improve product quality. The implementation of this standard, it marks the beginning of the quality control of down products in line with the international standards, and promoted the development of down products marketization, which indicates that the standardization work has entered a stage of development.

On February 1, 2012, the national standard GB/T 14272-2011 Down garments [1] was issued and implemented. The standard has increased product safety technology and children's safety performance, improved the testing methods of down content, filling power and garment seam slippage degree, etc, modified the inspection methods of appearance defect, stiching and other indexes of clothing, etc, and standardized terms and definitions of standards. In 2013, four industry standards of down bedding were issued and implemented after revised. The definition, terminology, test methods, inspection rules, marking, packaging, transportation and storage of all kinds of bedding products are clearly defined in the standard, the product is classified according to the composition component and the using function of the filler, and the international advanced detection technology and standard content are cited in the aspects of the quality of the down filler, the quality of the fabric, the quality of the fabric, the quality of the down filling and the quality of the down and the like.

On July 1,2017, the national standards GB/T 10288-2016 Test method for down and feather [2] and GB/T 17685-2016 Down and feather [3] were issued and implemented. The standards eliminated the definition of down content that has been used in China, eliminated the requirements and test methods for microbes, and added or revised the test methods for quill feather, categories, filling power, turbidity, fat and oil content, odour, acidity and moisture content.

The formulation of the new standards, it was reflected the development concept of internationalization and marketization of product quality, has certain foresight. It has followed the principle of advanced technology, reasonable economy, safety, reliability and coordination, the content is more perfect and reasonable. The standard level was obviously improved, which provides technical basis for product production and quality supervision.

At present, most of the down and feather and their products manufacturers in China can apply the requirements of these standard inspections, and qualification procedures to strengthen the quality control of down and feather and their products. However, there are some differences in the type of project and the limit value of the index between the national standards and the international standards.

\section{The Difference of the Standard Evaluation of Down and Feather at Home and Abroad}

\subsection{Identification Labels}

The European label of down and feather fillers applies to the EN12934 standard. The main contents are as follows: the percentage content of down and feather must be marked on the label, the label is divided into seven grades: I, II, III, IV, V, VI, VII, Only pure waterfowl feather filler (geese and ducks) were allowed to use three grades I, II and III, and only four 
grades IV, V, VI and VII could be used for mixed feather fillers of waterfowl and land fowl (chicken or turkey).

The USA published and implemented Product label guide of down and feather. The main contents are as follows: the type of label and conditions of use were proposed, the down products were divided into four categories: down products, down / feather mixed products, feather / down mixed products and feather products, and it is stipulated that the "down products" label can be used when the content of down was at least $75 \%$. In addition, in the hybrid fillers products, the ingredients up to or above $50 \%$ must be marked in front of the label, in the "feather product" label, the "waterfowl feather" may be marked, if the feather content of the duck and goose reaches $80 \%$. When the residue content exceeds $2 \%$, or the down fiber content exceeds $10 \%$, or the feather fiber content exceeds $10 \%$, or the land fowl feather / feather fiber content exceeds $5 \%$, or the damaged feather content exceeds $7 \%$, the specific percentage of these elements must be marked on the label. Types and content of down and feather, oxygen number, filling power, turbidity, the quantity of down fiber and feather fiber and the weight for fillers, must be clearly labeled.

Japan has formulated The representation of the quality of household goods, which requires that it be included in "fibre products for daily use (which fall under this category as well), synthetic resin products, electrical machinery, and miscellaneous industrial goods", it was generally difficult for consumers to identify "products that need to be identified with their quality in particular", they must be expressed in accordance with standard provisions. The main contents of product quality representation are: composition, performance, use, storage method, other matters relating to the representation of quality and those to be observed by the manufacturers, sellers or presenters.

At present, there is no special labelling standard for down garments in China. The classification and marking of down and feather fillers are not as detailed, standardized and accurate as those in Europe, the USA and Japan. Although the GB/T 14272-2011 Down Garments [1] explicitly stipulates that the GB 5296.4-2012Instructions for the use of products of consumer interest-Part 4: Textiles and apparel [20] shall be enforced in terms of products quality representation, the products must be named, down content, net fill weight and so on. But on the whole, the concept of "down" was used too broadly in China, and the scale and the level of technical quality management of down garments production enterprises were too broad. The gap is obvious, poor enterprises may not even understand the basic role of labels, to take the initiative, it is more difficult to use correctly. Some manufacturers call garment products down content less than $50 \%$ down clothing as "down garments", which is obviously less careful and precise than foreign countries in terms of quality. The lack of bound technical regulations or the degree of technical regulations is not strict, which results in weak quality control of Chinese down products, which is not conducive to the development of product quality.

\subsection{Physical Performance Items}

At present, the physical performance testing items in the domestic and international standards of down garments are mainly as follows: net fill weight, down content, the proportion of down in down content, filling power, composition analysis of the fabric, colour fastness, shrinkage and smoothness of fabric after washing or dry-cleaning, tensile / tearing / bursting strength of fabric, seam slippage strength, the down-proof properties of fabrics and water repellent property of fabric, etc (See Table 1, the national standards is based on GB/T14272-2011).

Table 1. Test items and technical requirements for physical properties of down garments in national standard and international standards.

\begin{tabular}{|c|c|c|c|c|c|}
\hline \multirow{2}{*}{\multicolumn{2}{|c|}{ Project type }} & \multicolumn{4}{|l|}{ Index limit value } \\
\hline & & GB standards & IDFB standards & EU standards & Japanese standards \\
\hline \multicolumn{2}{|l|}{ Net fill weight } & $\leq-5.0 \%$ & $\begin{array}{l} \pm(2-3) \% \text { or according to } \\
\text { the requirements of the } \\
\text { order contract }\end{array}$ & - & $\begin{array}{l} \pm(1-2) \% \text { or according to } \\
\text { the requirements of the } \\
\text { order contract }\end{array}$ \\
\hline \multicolumn{2}{|l|}{ Down content } & $\geq 50-3.0 \%$ & $\begin{array}{l}\text { No negative deviation } \\
\text { allowed }\end{array}$ & $\pm 5 \%$ & $-2 \%$ \\
\hline \multicolumn{2}{|c|}{ The proportion of down in down content } & $\geq 90 \%$ & - & - & - \\
\hline \multicolumn{2}{|l|}{ Fill power } & $\begin{array}{l}\text { Goose down: } \\
\geq(12.5-15.0) \mathrm{cm} \\
\text { Duck down: } \\
\geq(11.5-14.0) \mathrm{cm}\end{array}$ & $\begin{array}{l}\text { According to the } \\
\text { requirements of the } \\
\text { order contract }\end{array}$ & $\begin{array}{l}\text { According to the } \\
\text { requirements of the } \\
\text { order contract }\end{array}$ & $\begin{array}{l}\text { New species } \\
\geq 12.0 \mathrm{~cm} \\
\text { Prime article } \\
\geq 14.5 \mathrm{~cm} \\
\text { Luxury goods } \\
\geq 16.5 \mathrm{~cm}\end{array}$ \\
\hline \multicolumn{2}{|c|}{ Composition analysis of the fabric } & $\begin{array}{l}\text { Tolerances of more } \\
\text { than two } \\
\text { components } \pm 5 \% \text { (Ac } \\
\text { cording to } \\
\text { FZ/T01053 } \\
\text { regulations) }\end{array}$ & $\begin{array}{l}\text { Tolerances of more } \\
\text { than two components } \\
\pm 3 \%\end{array}$ & $\begin{array}{l}\text { Tolerances of more than } \\
\text { two components } \\
\pm 3 \%\end{array}$ & $\begin{array}{l}\text { In accordance with the } \\
\text { Japanese labelling act }\end{array}$ \\
\hline \multirow{3}{*}{$\begin{array}{l}\text { Colour } \\
\text { fastness of } \\
\text { fabric, level }\end{array}$} & \multirow{3}{*}{$\begin{array}{l}\text { Colour fastness to washing } \\
\text { with soap or soap and soda } \\
\text { Colour fastness to dry } \\
\text { cleaning }\end{array}$} & Change colour $\geq 3-4$ & Change colour 3 & Change colour3-4 & Change colour3-4 \\
\hline & & Staining $\geq 3$ & Staining4 & Staining4 & Staining4 \\
\hline & & (Non-claim) & 4 & 4 & 4 \\
\hline
\end{tabular}




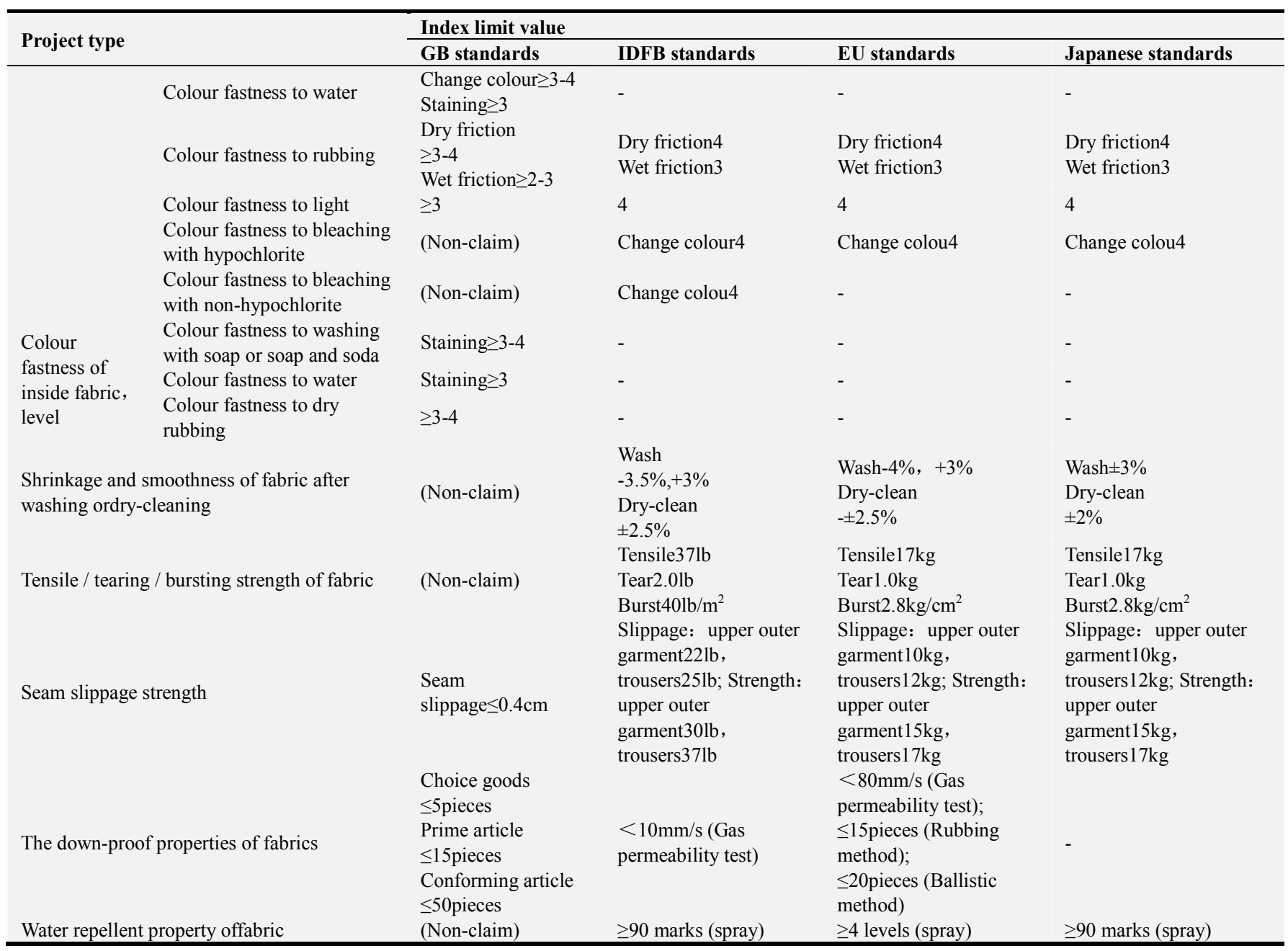

By comparing and analyzing the types and contents of these items, it can be seen that there are some differences between national and international standards in setting the types of projects and the limited values of indicators. The national standards are lower than the international standards for three physical items, such as net fill weight, fill power and composition analysis of the fabric. There is no requirement for the physical properties of three items of fabric, such as shrinkage and smoothness of fabric after washing or dry-cleaning, tensile / tearing / bursting strength of fabric and water repellent property offabric. These items in the EU standards, the IDFB and the Japanese standards are clearly defined.
At present, the chemical (safe and hygienic) performance testing items involved in the domestic and international standards of down garments are mainlyas follows: stock of harmful microorganisms in down, moisture content of down, oxygen number of down, fat and oil content of down, cleanliness of down, odour of down, banned azo dyestuff, banned carcinogenic and allergenic dyestuff, formaldehyde content, heavy metal content, the $\mathrm{pH}$, pesticide residue, sensory odour, PVC plasticizer, content of organic chloride carriers, fabric burning property and sharp residue, etc (See Table 2, the national standard is based on GB/T14272-2011).

\subsection{Chemical Performance Items}

Table 2. Test items and technical requirements for chemical properties of down garments in national standard and international standards.

\begin{tabular}{llll}
\hline \multirow{2}{*}{ Project type } & Index limit value & & \\
\cline { 2 - 4 } & GB standards & IDFB standards & EU standards \\
\hline $\begin{array}{l}\text { Mesophil aerobic bacteria of } \\
\text { down }\end{array}$ & $<10^{6} \mathrm{CFU} / \mathrm{g}$ & - & $<10^{6} \mathrm{CFU} / \mathrm{g}$ \\
$\begin{array}{l}\text { Faecal streptococci of down } \\
\text { Sulphite reducing clostridium of }\end{array}$ & $<10^{2} \mathrm{CFU} / \mathrm{g}$ & - & $<10^{2} \mathrm{CFU} / \mathrm{g}$ \\
$\begin{array}{l}\text { down } \\
\text { Salmonella of down }\end{array}$ & $\begin{array}{l}\text { Don't exist in } 20 \mathrm{~g} \\
\text { Moisture content of down }\end{array}$ & - & $<10^{2} \mathrm{CFU} / \mathrm{g}$ \\
$\begin{array}{l}\text { Oxygen number of down } \\
\text { Fat and oil content of down }\end{array}$ & $\leq 13.0 \%$ & - & Don't exist in $20 \mathrm{~g}$ \\
\hline
\end{tabular}




\begin{tabular}{|c|c|c|c|c|}
\hline \multirow{2}{*}{ Project type } & \multicolumn{4}{|l|}{ Index limit value } \\
\hline & GB standards & IDFB standards & EU standards & Japanese standards \\
\hline & & $\begin{array}{l}\text { requirements of the order } \\
\text { contract }\end{array}$ & & $\begin{array}{l}\text { requirements of the order } \\
\text { contract }\end{array}$ \\
\hline Cleanliness of down & $\geq 450 \mathrm{~mm}$ & $>300 \mathrm{~mm}$ & $>300 \mathrm{~mm}$ & $>500 \mathrm{~mm}$ \\
\hline Odour of down & $\leq 2$ level & No smell of decay & No smell of decay & No smell of decay \\
\hline The banned azo dyestuff & (Non-claim) & Not allowed to appear & Not allowed to appear & Not allowed to appear \\
\hline $\begin{array}{l}\text { The banned carcinogenic and } \\
\text { allergenic dyestuff }\end{array}$ & $\begin{array}{l}\text { Forbidden (According to } \\
\text { GB18401 regulations) }\end{array}$ & Not allowed to appear & Not allowed to appear & Not allowed to appear \\
\hline Formaldehyde content & $\begin{array}{l}\leq 300 \mathrm{mg} / \mathrm{kg} \text { (According to } \\
\mathrm{GB} / \mathrm{T} 18401 \text { regulations) }\end{array}$ & $\leq 300 \mathrm{mg} / \mathrm{kg}$ & $\leq 300 \mathrm{mg} / \mathrm{kg}$ & $\begin{array}{l}\text { Infant }{ }^{\prime} \text { s wearnot to } \\
\text { contain, other fabrics }< \\
75 \mathrm{mg} / \mathrm{kg}\end{array}$ \\
\hline $\begin{array}{l}\text { Heavy metal } \\
\text { content, } \mathrm{mg} / \mathrm{kg}\end{array}$ & (Non-claim) & - & $\begin{array}{l}\text { Antimony } \leq 10.0 \text {, } \\
\text { Arsenic } \leq 1.0 \text {, } \\
\text { Lead } \leq 1.0 \text {, } \\
\text { Cadmium } \leq 0.1 \text {, } \\
\text { Chromium } \leq 2.0 \text {, } \\
\text { Cobalt } \leq 4.0 \\
\text { Copper } \leq 50.0 \text {, } \\
\text { Nickel } \leq 4.0 \text {, } \\
\text { Mercury } \leq 0.02\end{array}$ & - 0 - \\
\hline $\mathrm{pH}$ & $\begin{array}{l}4.0-9.0 \text { (According to } \\
\text { GB18401 regulations) }\end{array}$ & - & $4.0-7.5,4.0-9.0$ & - \\
\hline Pesticide residue & (Non-claim) & - & $\leq 1.0 \mathrm{mg} / \mathrm{kg}$ & - \\
\hline Sensory odour & (Non-claim) & - & Not allowed to appear & - \\
\hline PVC plasticizer & (Non-claim) & - & $\leq 0.1 \%$ & - \\
\hline $\begin{array}{l}\text { Content of organic chloride } \\
\text { carriers }\end{array}$ & (Non-claim) & - & $\leq 1.0 \mathrm{mg} / \mathrm{kg}$ & - \\
\hline Fabric burning property & (Non-claim) & $\begin{array}{l}\text { Plain cloth }>3.5 \mathrm{~s} \\
\text { Hairy cloth }>7 \mathrm{~s}\end{array}$ & $>5 \mathrm{~s}$ (Sweden) & 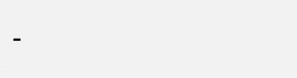 \\
\hline Sharp residue & (Non-claim) & 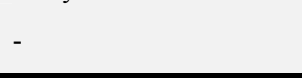 & - & $\begin{array}{l}\text { Not allowed (Metal } \\
\text { detection) }\end{array}$ \\
\hline
\end{tabular}

By comparing and analyzing the types and contents of these items, it can be seen that there are some differences between national and international standards in setting the types of projects and the limited values of indicators. The national standards are lower than the international standards for three physical items, such as oxygen number of down, fat and oil content of down and cleanliness of down. There are no requirements for eight chemical performance indexes such as the banned azo dyestuff, heavy metalcontent, pesticide residue, Sensory odour, PVC plasticizer, content of organic chloride carriers, fabric burning property and Sharp residue. These items are restricted in international standards, especially in EU standards.

\section{Prospects}

Emphasizing the role of label, paying attention to the cleaning of down products, the safe and healthy performance of down products, perfecting the testing items and setting the limit value strictly are the common requirements of international standards such as the USA, Europe and Japan.

In contrast, there are some differences between the requirements of national standards and international standards in terms of the complete range of inspection items, the establishment of limited values of test indexes and the label specifications.

The purpose of analyzing and summarizing the gap between national standards and international standards of down and feather and its products is to promote the standardization of Chinese down and feather products. Product standards are the basis of product production and the criterion of evaluating product quality. Without high level standards, there can be no high quality products. High standards will lead to the development of product quality and promote the improvement of product quality.

The only aim of China is to promote the development of product quality, by setting the limited values of the assessment indicators strictly, increasing and perfecting the examination items, and carry out the work of revising and perfecting the national standards, to promote the progress of production technology and the improvement of management level, to create conditions for the realization of specialization and international production, and to guarantee the stable improvement and sustainable development of down and feather product quality.

\section{Conclusion}

In this paper, the process and current situation of Chinese and international standardization of down products have been analyzed and compared. At present, there are some differences between the national standards and the international standards of down products in the aspects of inspection item type, setting of limit value of inspection index, and specification of label, etc. Objective understanding of the differences between domestic and international standardization of down products, it can 
promote the national standards of down products to be revised and perfected more quickly, and it is possible to provide some references in the standardization of down products. Of course, in the process of standardization of down industry in China, it needs to be based on the actual production of down products in our country, the quality characteristics of down products in our country, and the actual situation of the standardization of down products in our country, the purpose of continuously improving the international level of the standardization of the down industry in China will certainly be achieved.

\section{References}

[1] GB/T 14272-2011Down garments [S].

[2] GB/T 10288-2016 Test method for down and feather [S].

[3] GB/T 17685-2016 Down and feather [S].

[4] IDFB Testing Regulations Part 00-19 (Version 2017) [S].

[5] BS EN 1161:1997 Feather and down-Test methods-Determination of moisture content [S].

[6] BS EN 1162:1997Feather and down-Test methods-Determination of the oxygen index number [S].

[7] BS EN 1163:1997 Feather and down-Test methods-Determination of the oil and fat content $[\mathrm{S}]$.
[8] BS EN 1164:1999 Feather and down-Test methods-Determination of the turbidity of an aqueous extract [S].

[9] EN 12935:2001 Feather and down-Hygiene and cleanliness requirements [S].

[10] BS EN 1884:1999 Feather and Down-Test Methods-determination of microbiological state [S].

[11] Standard 100 by OEKO-TEX (Edition01.2019) Conditions for testing, certification and licensing according [S].

[12] JIS L 1903:2017 Testing methods for feathers [S].

[13] GB/T 10288-1988 Inspection method of feather for export [S].

[14] GB/T 10289-1988 Inspection method of washed feather for export $[\mathrm{S}]$.

[15] QB/T 1193-1991 Down quilt [S].

[16] QB/T 1194-1991 Down sleeper [S].

[17] QB/T 1195-1991 Down sleeping bag [S].

[18] QB/T 1196-1991 Down pillow [S].

[19] GB/T 10288-2003 Testing methods for down and feather [S].

[20] GB 5296.4-2012Instructions for the use of products of consumer interest-Part 4: Textiles and apparel [S]. 